\title{
English Oral Tradition for Tourists to Promote Environmental Conservation
}

\author{
Girindra Putri Ardana Reswari ${ }^{1 *}$, Fitri Alfarisy ${ }^{2}$, Maharani Patria Ratna ${ }^{3}$, and Nida \\ Fadhilah $^{4}$ \\ 1,2,3,4 Applied Foreign Languages, Vocational School, Universitas Diponegoro
}

\begin{abstract}
Currently, Indonesian tourism is preparing to open back to international tourism activities due to the Covid 19 pandemic. One of the factors that they need to prepare is sustainable development in terms of Environmentally Feasible, which emphasizes that the development process must be responsive and pay attention to efforts to preserve the environment (natural and cultural), and to a minimum, avoid adverse impacts that can reduce environmental quality and disturb the ecological balance. This research aims at giving a new approach to preserving the environment without reducing tourism activity. English version of the oral tradition in the tourism place is chosen to attract tourists' awareness in preserving the environment. This research is a case study of Kandri Tourism Village by using documents analysis and interviews. The results showed various oral traditions related directly to the environment, which are passed down from generation to generation by the community. The oral traditions are succeeded in being used to preserve the environment for the domestic tourist. However, this is not optimal when applied to foreign tourists due to two factors: limited terminology and cross-cultural understanding.
\end{abstract}

\section{Introduction}

Tourism is a sector that impacted massively due to pandemic Covid-19. Based on data from the Central Statistics Agency, the number of foreign tourists is decreased by 73.6 percent during January-November 2020. The government revealed that if everything is conducive, there is a possibility that in June or July 2021, foreign tours will re-open. Moreover, the Covid-19 vaccination program is currently running in Indonesia. To prepare the tourism places to re-open, preparing the local tourist places is a must. It is hoped that they could attract many foreign tourists after the gate is opened and bring back their good economic conditions.

One of the government's mainstay sectors in tourism development is tourism villages which can directly promote Indonesia's natural beauty while empowering the various potentials possessed by the community. Mastery of the English language will support and assist the tourism village development community in realizing their big dream, namely, going international. In addition, opportunities to promote tourism in the village are increasingly wide open so that more domestic and foreign tourists come to the village. This will encourage

* Corresponding author: girindra.reswari@live.undip.ac.id 
the economy to move more quickly towards the economic welfare of the people in the village, which is in line with Law no. 10 of 2009 on tourism. The regulation states that tourism development can positively impact society, such as improving community welfare, poverty and unemployment reduction, and environmental preservation.

Related to the various impacts on society, previous research found that it is true that tourism brings positive impacts in terms of economics. However, when we talk about the impact on the environment, the research found that it brings negative impacts compared to positive ones. [1] stated that environmental relations and tourism are not always symbiosis supportive and profitable. Thus, endeavors in conservation, appreciation, and education are carried out to strengthen the relationship between the two, but what happens currently is that there is a relationship between the two, it somehow brings out conflict.

Therefore, this research aims at giving a new approach to preserving the environment without reducing tourism activity. English version of the oral tradition in the tourism place was chosen to attract tourists' awareness in preserving the environment.

\subsection{Oral Tradition}

As an alternative solution, oral tradition is used to preserve the environment. Oral tradition is one of the historical sources that must be preserved. It records the past of humans who are not familiar with their writings, customs, beliefs, values, or daily experiences. Quoted from the website of the Ministry of Education and Culture (Kemdikbud), oral traditions are speech that has been passed down from generation to generation by the community, such as oral, fairy tales, recitation, rhymes, folk tales, or other oral expressions. It is a voice for those who do not know the writings of the past.

In terms of oral literary form, [2] describes the following, namely: (1) proverb-petitih (a sentence or expression that contains a deep, broad, precise, subtle, and figurative meaning), (2) pantun ( poetry that is numerous and is often pronounced on various occasions), (3) mantra (the oldest poetry in literature and various other regional languages), (4) pasambahan (a two-party conversation, a dialogue between the pangka and the alek to convey the aims and objectives with respect), (5) lyrical prose or kaba.

Based on their research in West Sumatera, Indonesia [3] found that the society believes oral traditions and stories are part of their life and norms control. One of the examples is a famous story, namely Rimbo Bunian. Rimbo Bunian is a type of forest that cannot be entered at any time by humans. The forests located in the hills of the Nagari or the village are overgrown by various fertile, large, and tall plants. Once upon a time, the tigers in the forest went into the villages for food. It indicates that the animal ran out of food in the forest. People believe that people have made a mistake by disrupting the forest ecosystem.

Another success story of oral tradition in preserving culture is written by [4]. The research-proven that the ecological consciousness is contained in William Wordsworth's poetry poems and succeeds in serving human beings and make them aware of protecting the environment from pollution. William Wordsworth was one of the poets who admired nature; the description of nature was reflected in most of his poems. An example of Wordsworth's famous poems is "The World is Too Much with Us" written in 1802 and published in 1807. This poem is Wordsworth's story on the frustration of human's treatment of nature and denies the natural elements of nature:

The world is too much with us; late and soon

Getting and spending, we lay waste our power:

Little we see in nature that is our;

We have given our hearts a way, a sordid boon!

This sea that bears her bosom to the moon;

The winds that will be howling at all hours,

And are up -gathered now like sleeping flowers; (lines 1-8). 


\subsection{English for Tourism}

Previous research in Indonesia has already proved that English in Tourism is essential. [5] stated that English has an essential role as a communication tool for business and marketing, mainly in the tourism and hotel industry. It is supported by [6], who found that basically, the whole process of communication with foreign tourists requires foreign language skills and mastery. The role of foreign languages is improving our tourism. Among others, it is for tourism promotion outside the country, reservation services, accommodation services (hotels or trips), services during guiding, and communication of foreign tourists with the community. [7] also stated that English has become a world language, this language then becomes a part of international travel from tourism brochures to window signs in every shop. Even if some countries still use their language, those tourism entities have a parallel version in English.

\section{Methods}

This research is a case study of Kandri Tourism Village by using documents analysis and interviews. Kandri Tourism Village is chosen since it is one of the tourist villages that are the mainstay of tourism in the city of Semarang. This village has various tourism potentials such as physical tourism objects, namely Goa Kreo and Jatibarang Reservoir; the demographics of the village which are located on a mountain with a variety of beautiful natural scenery and the air is still cool, and various traditional arts, cultural performances, and traditional culinary. Based on the interview, before the Covid19 pandemics, Kandri is becoming the place of international students and educational tourist activity such as the AIESEC Program, Summer Camp, and international school live.

[8] explained that a case study is an approach that involves the specific and detailed study of a case. Case studies also can be limited to one type of situation. Further, it is explained that a case study is an appropriate approach when examining a particular programme and its relation to design, analysis, and interpretation.

The first data collection used in this research is the interview. The interview is done by interviewing the Kandri Tourism Village management consist of the local government or village, village or sub-district government administrators, and the community as tourism actors. The type of interview that will be used in this research is a semi-structured interview. [9] explained that under semi-structured interviews, interview questions are standardised. Therefore, comparison and analysis of the data are easier to conduct.

The second data collection that will be used in this research is document analysis. [10] described document analysis as a systematic procedure for reviewing or evaluating documents. In this research, data collection is done by looking at some oral traditions that have been written in their profile book for promotion purposes.

\section{Results and Discussion}

\subsection{Oral Tradition at Kandri Tourism Village}

The interview and document analysis showed that some oral traditions are still being preserved and believed by the local society at Kandri Tourism Village. These oral traditions are mostly related to the sacred places, namely spring bath or sending in Bahasa Indonesia. 
Kandri village is famous with their spring baths that believed to have its own efficacy, those are:

1. Sendang Gede

2. Sendang Jambu/ Sendang Jamu

3. Sendang Pancuran

4. Sendang Gawe

Those spring baths are still actively used by society until now. The amount of water is still abundant and could be used to be the water source for social activities such as irrigation for the rice fields and fishponds, bathing, washing, or doing some rituals and medications. The traditional ceremonies are being held as an expression of being grateful for what God gives to them.

Besides conducting the ceremony as an expression of thankfulness to God, some oral traditions of the spring baths as beliefs are being told by the locals. During the interviews, the management of the village explained that it is part of the tour guide duty to explain the oral traditions to the visitors when they are visiting the spring baths. The visitors should understand the oral traditions since they must be followed during their visit and must not be violated. Based on the document study, the oral tradition also has been written in their profile book that the visitors can access.

The oral tradition that they preserve is mainly related to what you should do and not do while visiting or take a bath in the spring bath. It could be concluded as follows:

1. Do not criticize the water or anything in the spring bath

2. Visitors are not allowed to wash household utensils / cooking utensils in the spring bath

3. When visitors are joking, it is advisable not to make someone cry. If crying, it is advisable to get out of the spring

4. If you want to take water to take home, it must be known beforehand by the caretaker (Mr Kyai Ahmad Supriyadi)

5. If a visitor sees anything that seems strange, do not disturb or ignore it

6. If visitors take a bath with the intention of treatment, they should bathe in after 12 o'clock in the evening

When it comes to the question of "does the oral tradition works to attract tourists", the answers from the interviewees are yes. They explained that people are usually coming intending to understand the tradition. Therefore, having an oral tradition based on a real place such as a spring bath makes the visitors interested.

Further, answering the following research question on "does oral tradition impact the behaviour of the visitors" the answer is also yes. It is explained that the list of what you should do and not do makes the visitors more careful about behaving. Specific to the environmental behaviour, the oral tradition works as a rule for the visitors to keep the place clean and not polluted.

Results of the interview with the local people of Kandri village, almost all societies believe the oral traditions. They said that it makes them afraid to make the place dirty or do something inappropriate on the site. They also said that make it out of the belief system, and the oral tradition wants us to keep the place clean and not polluted the spring bath because it is the water source for all the activities in the village. Therefore, the water and the place of water should be protected. 


\subsection{Oral Tradition for the Tourist}

Even if oral tradition is well maintained by the village, the management, or local people who also work as a guide said that it is somehow problematic to deliver the oral tradition to international tourists. The cultural environment is the basis for the memory and identity of the community and the people. It is a massive national heritage that includes essential social and cultural values when well taken care of, regionally characteristic and constructed out of different periods. Systematic maintenance and enhancement of the cultural environment increases the vitality and attractiveness of areas, help to implement sustainable development, and sustain the national heritage values.

The result of the document study found that there are bilingual profile books already which contain the oral traditions as a product of a community service group from a university in Semarang. However, the interview result showed that when it comes to further explanation, the local societies and local guides are having difficulties explaining further. It is because of two things: complicated Javanese terminology and cross-cultural understanding.

\subsubsection{Difficult Javanese Terminology}

Since the oral traditions existed for a long time ago, the Javanese language is still often used as a specific terminology. One example is the explanation of the ceremony of the spring bath. It uses many Javanese words such as Kliwon, Jumadil akhir, nyadran, and many more. Since this is a tourism village while the tour guides are coming from their societies, the interview results found that almost all local societies only speak basic English as a daily conversation. They tend to memorize the story that they usually use to explain to foreign tourists. It also happens to tourists. Since the tourists coming to Kandri Village are usually from educational purposes, they usually can speak Bahasa Indonesia. Unfortunately, they are not familiar with the use of Javanese specific terminology as mentioned before.

[11] argued that results of the analysis showed that there are psychological problems that usually become the primary reason for English speaking difficulties (e.g. nervousness, fear of making mistakes, and lack of confidence), followed by linguistic problems (e.g. insufficient vocabulary), and environmental problems (e.g. lack of learning context for English conversation).

As this research focuses on environmental conservation, English speaking comprehension should be mastered by the local societies. It is because language plays an important role to send the message to the tourist. They have to understand the oral tradition message to follow the rules as what has successfully influenced the domestic visitors.

Speakers should master the language as the essential component in communication to ensure that there is no miss understanding, especially when it comes to interlanguage and intercultural speakers. The receiver, upon receiving the message, attempts to decode and understand the meaning of the message. The communication process is completed when the receiver understands the message the way the sender intended it. The challenge of carrying out communication successfully in a cross-cultural context is to acknowledge and overcome cultural differences that impact how a message is communicated and interpreted by the sender and receiver. A particular word or expression may hold different meanings for the sender and the receiver, and misinterpreting the message can result in a failed message [12]. 


\subsubsection{Cross-cultural Understanding}

As mentioned earlier, the oral tradition generally contains traditions and habits that live and develop in the community. Oral tradition also works as a rule to preserve the nature of the place. Oral tradition stories originating from various regions in Indonesia contains norms of life that are good as examples in life every day, not only in a limited social environment but also in the environment of the broader community at large. From the content of the oral story, it will be known that there are differences that are sometimes difficult to understand or accept by other communities, especially by foreigners. Therefore, it is necessary presumably to socialize with other communities, including foreign nationals that come, about the various norms that exist in society to make sure that misunderstanding does not occur.

Results of the interview showed that sometimes it is hard to explain to tourists that coming from a country with no strong culture or beliefs. The management teams of Kandri and the local societies mentioned that sometimes the tourists would ask them many things because it seems that it does not make any sense.

According to [13], the home society has to teach the tourists by using a direct cultural experience. Cultural experience is cultural preservation that is done in a way directly involved. At the same time, the legends that exist and live in the community in various regions in Indonesia are extraordinary treasures. Some places that have a legend, which is still alive within the community that owns it, have their charm both for the surrounding community and people from outside the region, even for people from abroad country. Some places have even become (cultural) tourist areas no stranger to the Indonesian nation and other nations. Places it is in great demand by people from outside the area, including tourists and researchers from other countries. Therefore, local society should not be afraid of the questions coming from the local tourists since it is part of their goal to do the journey, which is to get the cultural experience and knowledge [14].

[14] stated that each region has its own culture, which is still retained as a peculiarity. This, of course, makes a variety of cultures in Indonesia, which simultaneously gave rise to various traditions that can be seen from various perspectives, including religion, heroism, custom customs, and nature.

The idea of preserving the environment through oral tradition, especially for people from other cultures, is in line with [15], who stated that people are responsible for the excellent maintenance of the environment they live in. Everyone also has the right to a good cultural environment. An excellent cultural environment means different things to different people. However, the common feature of all cultural environments that people see as good is strengthening the relationship people have with their living environment. They help to understand the present and build the future through the past.

\section{Conclusion}

Tourism is one of the sectors that get a massive influence due to pandemic Covid 19. The government revealed that if everything is conducive, there is a possibility that in June or July 2021, foreign tours will re-open. Moreover, the Covid-19 vaccination program is currently running in Indonesia. To prepare the tourism places to re-open, preparing the local tourist places is a must. However, as Indonesia had before pandemics Covid-19, active tourism also led to a problematic issue, that is, environmental issue. To reach minimum negative impacts that can reduce environmental quality and disturb the ecological balance, a strategic solution should be given to local tourism. This research aims at giving a new approach to preserving the environment without reducing tourism activity. 
Oral tradition is chosen to be used to preserve the environment. There are no specific problems for domestic tourists. However, for international tourists, two things are becoming challenges. Those are limited terminology and cross-cultural understanding. In order to achieve the maximum effort of environmental conservation, the local guides, societies, and tourism village management should start to conduct some training on the English language, specifically vocabulary. Another thing is that the tourism villages guides, societies, and tourism management should understand that they are responsible for the good maintenance of the environment in which they live. Everyone also has the right to a good cultural environment. A good cultural environment means different things to different people. However, the common feature of all cultural environments that people see as good is strengthening the relationship people have with their living environment. They help to understand the present and build the future through the past.

\section{References}

[1] I. Ismayanti, I. Djamhur, and L. Levyda, "Indonesian Tourists' Preferences Influence of Conscious and Unconscious Motives," The Winners, vol. 12, no. 1, p. 11, (2011), doi: 10.21512/tw.v12i1.680.

[2] E. Sone, "African Oral Literature and the Humanities: Challenges and Prospects," Humanities, vol. 7, no. 2, p. 30, (2018), doi: 10.3390/h7020030.

[3] S. Anwar, R. Akbar, M. Akbar, and A. Azhar, "Measuring the Size of Under Ground Economy in Pakistan : A Microeconomic Approach Measuring the Size of Under Ground Economy in Pakistan : A Microeconomic Approach," J. Appl. Environ. Biol. Sci., vol. 7, no. 8, pp. 84-93, (2017).

[4] Y. Zhang, "Cooperative language learning and foreign language learning and teaching," J. Lang. Teach. Res., vol. 1, no. 1, pp. 81-83, (2010).

[5] R. Sri Rahayu, "Studi Literatur: Peranan Bahasa Inggris Untuk Tujuan Bisnis Dan Pemasaran," vol. 1, no. 4, p. 149, (2018).

[6] A. Setyanto, "Pentingnya penguasaan bahasa dan budaya asing sebagai pendukung utama sektor pariwisata," (2012).

[7] G. Raţă, I. Petroman, and C. Petroman, The English of Tourism The English of Tourism, no. November. Newxastle upon Tyne: Cambridge Scholar Publishing, (2012).

[8] M. Maxwell et al., "A qualitative study of primary care professionals' views of case finding for depression in patients with diabetes or coronary heart disease in the UK," BMC Fam. Pract., vol. 14, no. 1, pp. 1-8, (2013).

[9] L. Cohen, L. Manion, and K. Morrison, Research methods in education. routledge, (2013).

[10] G. A. Bowen, "Document Analysis as a Qualitative Research Method," Qual. Res. J., vol. 9, no. 2, pp. 27-40,(2009), doi: 10.3316/QRJ0902027.

[11] M. Shen and T. Chiu, "EFL Learners' English Speaking Difficulties and Strategy Use," Educ. Linguist. Res., vol. 5, no. 2, p. 88, doi: 10.5296/elr.v5i2.15333, (2019).

[12] S. Rabiah, "Language as a Tool for Communication and Cultural Reality Discloser," pp. 1-11, 2018, doi: 10.31227/osf.io/nw94m, (2018).

[13] S. Abrar-ul-Hassan, "State-of-the-art review: Revisiting the ins and outs of ESP practice," Prof. Acad. English, vol. 39, pp. 4-11, (2012).

[14] Y. Bagas Arwansyah, "Revitalizing Local Culture As the Basis for Scientific," vol. 5, no. 1, (2019).

[15] P. Viitanen and P. Arhinmäki, Cultural Environment Strategy 2014-2020, no. March 2014. (2014). 